\title{
PROFIL KEMAMPUAN KOMUNIKASI DAN PEMAHAMAN MATEMATIS SISWA BERDASARKAN TIPE KEPRIBADIAN EXTROVERT DAN INTROVERT
}

\author{
1) Mutiara Siska*, ${ }^{2)}$ Jefri Marzal, ${ }^{3)}$ Muhammad Haris Effendi \\ 1, 2, 3) Program Studi Magister Pendidikan Matematika, Universitas Jambi \\ ${ }^{1)}$ mutiarassk@gmail.com, ${ }^{2)}$ jefri.marzal@unja.ac.id, ${ }^{3)}$ hariseffendi@unja.ac.id
}

Received:
20/05/2020
Accepted:
07/07/2020
Published:
12/07/2020

Abstrak

Metode deskriptif yang bertujuan untuk mendeskripsikan profil kemampuan komunikasi dan pemahaman matematis berdasarkan tipe kepribadian extrovert dan introvert. Pendekatan yang digunakan yaitu kualitatif-kuantitatif. Subjek penelitian siswa kelas V SD dengan 1 siswa extrovert dan 1 siswa introvert. Pemilihan subjek berdasarkan teknik pengambilan cluster sampling dan purposive sampling. Berdasarkan hasil penelitian dapat disimpulkan bahwa profil kemampuan komunikasi matematis tertulis siswa extrovert cukup dengan persentase $75 \%$ dan profil kemampuan komunikasi matematis tertulis siswa introvert baik dengan persentase $81,25 \%$. Profil kemampuan komunikasi matematis lisan siswa extrovert baik dengan persentase $81,25 \%$ dan profil kemampuan komunikasi matematis lisan siswa introvert kurang dengan persentase $56,25 \%$. Profil kemampuan pemahaman matematis siswa extrovert baik dengan persentase $81,25 \%$ dan profil kemampuan pemahaman matematis siswa introvert sangat baik dengan persentase $87,50 \%$.

Kata Kunci: Tipe Kepribadian Extrovert dan Introvert, Komunikasi Matematis, Pemahaman Matematis

\section{Pendahuluan}

Dalam belajar, kepribadian siswa mempengaruhi proses pembelajaran. Karena perbedaan kepribadian setiap siswa maka cara mereka untuk belajar juga berbeda. Menurut Dewiyani (Widiyanti, 2016) penting bagi guru untuk mengetahui berbagai karakteristik kepribadian siswanya. Hal ini sesuai dengan pernyataan Ulya (2016) bahwa guru harus mengetahui kepribadian siswa agar mampu menentukan model atau metode pembelajaran yang berdampak pada peningkatan kualitas pembelajaran serta hasil belajar siswa.

Keywords: Type of Extrovert and Introvert Profile, Mathematical
Communication, Mathematical Comprehension

Keywords: Type of Extrovert and Introvert Profile, Mathematical
Communication, Mathematical Comprehension

\begin{abstract}
Descriptive method that aimed to describe a profile of communication ability and and introvert. The approach that was used in this research was qualitativequantitative. The research subject is student's grade five of elementary school on technique of cluster sampling and purposive sampling. Based on the result of extrovert student was enough with the percentage was $75 \%$ and profile of written $81,25 \%$. Profile of oral mathematical ability of extrovert student was good with the percentage was $81,25 \%$ and profile of oral mathematical ability of introvert comprehension ability of extrovert student was good with the percentage was $81,25 \%$ and profile of mathematical comprehension ability of introvert student was very good with the percentage was $87,50 \%$.
\end{abstract}


Menurut Eysenck (Ulya, 2016) seseorang dapat dibedakan menjadi dua tipe kepribadian, yaitu extrovert dan introvert. Kepribadian mempengaruhi pembelajaran (Brewer, 2006), sehingga penting untuk mengetahui seorang siswa memiliki tipe kepribadian extrovert atau introvert. Guru perlu untuk mengetahui tipe kepribadian siswanya dalam pembelajaran agar guru dapat mengembangkan kemampuan mereka, sehingga mereka mendapat hasil yang memuaskan dalam proses belajar.

Salah satu isu penting dalam pembelajaran matematika saat ini adalah pentingnya kemampuan komunikasi matematis siswa. Komunikasi matematis juga menjadi salah satu tujuan pembelajaran matematika dan menjadi salah satu standar kompetensi lulusan dalam bidang matematika.

Berdasarkan pengalaman penulis mengajar di dalam kelas terdapat beberapa permasalahan, seperti: (1) siswa kurang tepat dalam merefleksikan gambar atau masalah ke dalam ide matematika, (2) siswa tidak tepat dalam menuliskan simbol matematika, (3) siswa kurang tepat menafsirkan simbol matematika, (4) siswa kurang tepat dalam menyajikan data ke dalam diagram. Hal-hal ini merupakan permasalahan yang berkaitan dengan kemampuan komunikasi matematis, yaitu komunikasi matematis secara tertulis maupun secara lisan. Hal-hal ini jika berlanjut dapat menyebabkan kesalahan pemahaman konsep pada siswa. Dengan adanya permasalahan ini, maka perlu untuk di gali lebih lanjut tentang deskripsi komunikasi matematika siswa.

Berbagai penelitian menunjukkan bahwa komunikasi matematis memiliki peran dalam prestasi belajar siswa. Menurut Astuti dan Leonard (2015) "Prestasi belajar siswa akan semakin baik jika kemampuan komunikasi matematis ditingkatkan. Jadi untuk meningkatkan prestasi belajar siswa harus terlebih dahulu meningkatkan kemampuan komunikasi matematis siswa." Komunikasi matematika siswa merupakan interpretasi dan ekspresi dari pemahaman matematis siswa tersebut.

Ausubel (Kurniasi, 2016) menyatakan bahwa pengetahuan yang sudah dimiliki peserta didik akan sangat menentukan bermakna tidaknya suatu proses pembelajaran. Sehingga penting untuk mengetahui pemahaman matematis siswa agar tujuan pembelajaran tercapai.

Maka dalam proses belajar komunikasi matematis, pemahaman matematis, serta kepribadian siswa merupakan hal penting. Karena itu perlu untuk mengetahui profil kemampuan komunikasi dan pemahaman matematis siswa berdasarkan tipe kepribadian extrovert dan introvert, tetapi belum ada profil yang memperlihatkan tentang hal ini, sedangkan ini penting untuk di ketahui terutama oleh guru. Berdasarkan hal tersebut, penulis tertarik untuk melakukan penelitian ini. Adapun tujuan penulisan artikel ini adalah untuk 1) mengetahui profil kemampuan komunikasi matematis lisan siswa bertipe kepribadian extrovert dan introvert, 2) mengetahui profil kemampuan komunikasi matematis tulisan siswa bertipe kepribadian extrovert dan introvert, 3) mengetahui profil kemampuan pemahaman matematis siswa bertipe kepribadian extrovert dan introvert.

\section{Metode Penelitian}

Metode penelitian yang digunakan dalam penelitian ini adalah metode deskriptif. Penelitian deskriptif merupakan akumulasi data dasar dalam cara deskriptif, pendekatan 
yang digunakan kualitatif-kuantitatif (Marsigit, 2012). Pemilihan metode deskriptif tersebut didasari oleh tujuan peneliti yang ingin mendeskripsikan profil kemampuan komunikasi dan pemahaman matematis berdasarkan tipe kepribadian ekstrovert dan introvert. Data hasil penelitian akan di deskripsikan untuk memperoleh gambaran alami (profil) kemampuan komunikasi dan pemahaman matematis berdasarkan tipe kepribadian ekstrovert dan introvert.

Subjek dalam penelitian ini adalah siswa kelas 5 SD Bina Kasih Jambi. Pemilihan subjek penelitian berdasarkan teknik pengambilan cluster sampling dan purposive sampling. Subjek dipilih menggunakan metode cluster sampling. Cluster sampling digunakan bila pemilihan sampel sumber data sangat luas sehingga pengambilan sampel berdasarkan daerah populasi yang telah ditetapkan (Sugiyono, 2013: 121). Dalam hal ini, peserta didik diberi angket penggolongan tipe kepribadian menggunakan tes MBTI (Myer Briggs Type Indicator) untuk menggolongkan ke dalam kelompok tipe extrovert dan introvert.

Tabel 1 Kriteria Penskoran Komunikasi Matematis Lisan

\begin{tabular}{|c|c|}
\hline Skor & Kriteria Jawaban dan Alasan \\
\hline 4 & $\begin{array}{l}\text { - Menggunakan bahasa matematika (istilah, simbol dan tanda) yang sangat efektif, akurat dan } \\
\text { menyeluruh untuk menggambarkan operasi, konsep dan proses } \\
\text { - Solusi benar dan strategi yang sesuai ditunjukkan dengan tabel yang benar, ada deskripsi }\end{array}$ \\
\hline 3 & $\begin{array}{l}\text { - Menggunakan bahasa matematika (istilah, simbol dan tanda) yang sangat efektif, akurat dan } \\
\text { menyeluruh untuk menggambarkan operasi, konsep dan proses } \\
\text { - Sesuatu yang lengkap, strategi yang ditunjukkan atau dijelaskan tapi solusi yang tidak benar } \\
\text { - Solusi yang benar dan strategi yang sesuai ditunjukkan tapi tidak dilabelkan secara benar }\end{array}$ \\
\hline 2 & $\begin{array}{l}\text { - Menggunakan bahasa matematika yang minimal efektif dan akurat } \\
\text { - Solusi benar dengan strategi yang tidak sesuai atau penjelasan tidak ditunjukkan } \\
\text { - Beberapa bagian strategi yang sesuai ditunjukkan tapi tidak lengkap. } \\
\text { - Beberapa bagian strategi ditunjukkan dengan beberapa bagian yang tidak sesuai }\end{array}$ \\
\hline 1 & $\begin{array}{l}\text { - Menggunakan bahasa matematika yang tidak akurat } \\
\text { - Respon salah, ditunjukkan dengan penjelasan tertulis meskipun tidak terselesaikan } \\
\text { - Ada beberapa pekerjaan atau penjelasan menyalin data kembali, tetapi pekerjaan tidak } \\
\text { mengarah pada solusi yang tepat } \\
\text { - Tidak terdapat strategi penyelesaian } \\
\text { - Satu atau lebih pendekakatan tidak dijelaskan }\end{array}$ \\
\hline 0 & $\begin{array}{l}\text { - Tidak ada solusi diberikan } \\
\text { - Tidak terbaca, kosong atau tidak mencukupi untuk skor } \\
\text { - Tidak dikerjakan atau tidak ada solusi yang ditunjukkan } \\
\text { - Solusi tidak benar. Beberapa data dari masalah disalin, tetapi tidak ada bukti dari strategi } \\
\text { apapun ditampilkan atau dikerjakan }\end{array}$ \\
\hline
\end{tabular}

Sumber: Sulthani

Purposive sampling adalah teknik menentukan sampel dengan pertimbangan tertentu (Sugiyono, 2012: 85). Di pilih siswa dengan nilai ulangan pada materi prasyarat terbaik untuk tiap masing-masing tipe kepribadian, yaitu nilai tertinggi untuk siswa dengan tipe kepribadian extrovert dan introvert. Hal ini dilakukan agar siswa yang menjadi subjek merupakan siswa yang memiliki pemahaman matematis yang baik.

Sebelum memulai penelitian, peneliti menyiapkan instrumen penelitian terlebih dahulu dan memvalidasi instrumen tersebut. Instrumen yang di gunakan dalam penelitian ini yaitu instrumen tes tertulis, tes lisan, angket penggolongan tipe 
kepribadian dan lembar observasi. Setelah instrumen penelitian di validasi, peneliti menentukan subjek penelitian. Peserta didik kemudian diberi angket penggolongan tipe kepribadian menggunakan tes MBTI (Myer Briggs Type Indicator) untuk menggolongkan ke dalam kelompok tipe extrovert dan introvert. Instrumen yang di gunakan dalam penelitian ini menggunakan instrumen penelitian pada angket yang digunakan oleh Tarmidzi (2012).

Tabel 2 Kriteria Penskoran Komunikasi Matematis Lisan

\begin{tabular}{|c|c|}
\hline Skor & Kriteria Jawaban dan Alasan \\
\hline 4 & $\begin{array}{l}\text { - Memberikan respon lengkap dengan penjelasan } \\
\text { - Memberikan penjelasan dengan tidak ambigu } \\
\text { - Penjelasan terstruktur dari mulai yang diketahui, ditanya, jawaban dan dasar teori } \\
\text { - Berkomunikasi secara efektif kepada khalayak yang terinditifikasi } \\
\text { - Menyajikan argumen yang kuat secara logis dan lengkap disertai dasar teori sekaligus } \\
\text { menyertai contoh-contoh }\end{array}$ \\
\hline 3 & $\begin{array}{l}\text { - Memberikan respon yang cukup lengkap dengan penjelasan atau deskripsi cukup jelas. } \\
\text { - Penjelasan terstruktur dari mulai yang diketahui, ditanya, jawaban dan dasar teori } \\
\text { - Menyajikan mendukung argumen yang logis tapi mungkin mengandung beberapa celah kecil } \\
\text { seperti kesalahan dalam menyampaikan teori }\end{array}$ \\
\hline 2 & $\begin{array}{l}\text { - Belum mampu memberikan respon } \\
\text { - Penjelasan kurang terstruktur dari mulai yang diketahui, ditanya, jawaban dan dasar teori } \\
\text { - Melakukan lompatan-lompatan dalam menjelaskan jawaban tetapi masih mengetahui } \\
\text { hubungannya } \\
\text { - Memberikan penjelasan atau deskripsi yang ambigu atau tidak jelas } \\
\text { - Komunikasi sulit untuk ditafsirkan } \\
\text { - Argumen tidak lengkap atau didasarkan pada premis yang tidak logis }\end{array}$ \\
\hline 1 & $\begin{array}{l}\text { - Belum mampu memberikan respon atau feedback } \\
\text { - Memiliki beberapa unsur yang memuaskan pada saat menjelaskan tetapi mungkin gagal untuk } \\
\text { menyelesaikan atau mungkin menghilangkan bagian-bagian penting dari masalah } \\
\text { - Penjelasan atau deskripsi mungkin hilang atau sulit untuk di ikuti tetapi masih mampu } \\
\text { menjelaskan } \\
\text { - Penjelasan kurang terstruktur dari mulai yang diketahui, ditanya, jawaban dan dasar teori. } \\
\text { Melakukan lompatan-lompatan dalam menjelaskan jawaban tidak mengetahui hubungannya }\end{array}$ \\
\hline 0 & $\begin{array}{l}\text { - Berkomunikasi tidak efektif, kata-kata tidak mencerminkan masalah } \\
\text { - Penjelasan atau deskripsi tidak sesuai dengan masalah } \\
\text { - Penjelasan tidak terstruktur } \\
\text { - Tidak dapat memberikan respon atau feedback } \\
\text { - Tidak dapat menyampaikan dasar teori }\end{array}$ \\
\hline
\end{tabular}

Sumber: Sulthani

Setelah di dapatkan subjek penelitian dengan siswa yang memiliki tipe kepribadian extrovert dan introvert maka dilaksanakan proses belajar mengajar. Pada setiap pertemuan selain di laksanakan observasi kemampuan komunikasi matematis lisan, juga dilakukan tes kemampuan komunikasi matematis tertulis dan kemampuan pemahaman matematis. Kemudian data-data yang didapat tersebut di analisis oleh peneliti.

Untuk melihat ketercapaian indikator kemampuan komunikasi matematis siswa maka di susun rubrik penskoran melalui Holistic Scoring Rubrics seperti pada Tabel 1 untuk kemampuan komunikasi matematis tertulis dan Tabel 2 untuk kemampuan komunikasi matematis lisan. 
Ketercapaian indikator kemampuan pemahaman matematis siswa digunakan rubrik penskoran melalui Holistic Scoring Rubrics seperti pada Tabel 3.

Tabel 3 Kriteria Penskoran Pemahaman Matematis

\begin{tabular}{cl}
\hline \hline $\begin{array}{c}\text { Skor } \\
4\end{array}$ & $\begin{array}{l}\text { Kriteria Jawaban dan Alasan } \\
\text { Menunjukkan pemahaman konsep danprinsip terhadap soal matematika, penggunaan istilah dan } \\
\text { notasi matematika secara tepat, penggunaan algoritma secara lengkap dan benar }\end{array}$ \\
\hline 3 & $\begin{array}{l}\text { Menunjukkan pemahaman konsep danprinsip terhadap soal matematika hampir lengkap, } \\
\text { penggunaan istilah dan notasi matematika hampir benar, penggunaan algoritma secara lengkap, } \\
\text { perhitungan secara umum benar, namun mengandung sedikit kesalahan }\end{array}$ \\
2 & $\begin{array}{l}\text { Menunjukkan pemahaman konsep danprinsip terhadap soal matematika kurang lengkap dan } \\
\text { perhitungan masih terdapat sedikit kesalahan }\end{array}$ \\
1 & $\begin{array}{l}\text { Menunjukkan pemahaman konsep danprinsip terhadap soal matematika sangat terbatas dan } \\
\text { sebagian besar jawaban masih mengandung perhitungan yang salah } \\
0\end{array} \quad$ Tidak menunjukkan pemahaman konsep dan prinsip terhadap soal matematika \\
\hline
\end{tabular}

Untuk menghitung persentase skor dapat di gunakan rumus:

$$
\text { Persentase skor }=\frac{\text { jumlah skor }}{\text { jumlah skor maksimum }} \times 100 \%
$$

Selanjutnya setelah di dapat persentase skor tingkat kemampuan siswa tersebut dapat di lihat pada Tabel 4.

Tabel 4 Kategori Kemampuan

\begin{tabular}{cc}
\hline \hline Tingkat Kemampuan & Kategori \\
\hline $86 \leq x \leq 100$ & Sangat Baik \\
$76 \leq x<86$ & Baik \\
$60 \leq x<76$ & Cukup \\
$55 \leq x<60$ & Kurang \\
$0 \leq x<55$ & Kurang Sekali \\
\hline
\end{tabular}

Sumber: Purwanto (2014)

Setelah data tersebut selesai di analisis maka di peroleh deskripsi profil kemampuan komunikasi dan pemahaman matematis berdasarkan tipe kepribadian ekstrovert dan introvert.

\section{Hasil dan Pembahasan}

Seluruh siswa kelas $\mathrm{V}$ di beri angket penggolongan tipe kepribadian menggunakan tes MBTI (Myer Briggs Type Indicator) untuk menggolongkan ke dalam kelompok tipe extrovert (eks) dan introvert (int), hasil penggolongan yang telah di olah dapat di lihat pada Tabel 5 .

Tabel 5 Hasil Penggolongan Tipe Kepribadian Siswa Kelas V

\begin{tabular}{cccccc}
\hline \hline \multirow{2}{*}{ Kelas } & \multicolumn{2}{c}{ Laki-laki } & \multicolumn{2}{c}{ Perempuan } & Jumlah \\
\cline { 2 - 4 } & Eks & Int & Eks & Int & \\
\hline \hline A & 13 & 4 & 13 & 3 & 33 \\
B & 14 & 3 & 15 & 1 & 33 \\
C & 15 & 2 & 11 & 5 & 33 \\
\hline
\end{tabular}


Untuk mencapai tujuan penelitian, peneliti mendata hasil ulangan yang telah di peroleh oleh siswa pada materi prasyarat yaitu perbandingan, kemudian peneliti mengambil 2 orang dengan nilai tertinggi sebagai subjek penelitian, yaitu 1 orang siswa yang memiliki tipe kepribadian extrovert dan 1 orang siswa yang memiliki tipe kepribadian introvert. Penelitian ini dilakukan sebanyak 5x pertemuan dan dilakukan setelah proses belajar mengajar selesai dilaksanakan.

Untuk hasil kemampuan komunikasi matematis tertulis siswa berdasarkan tipe kepribadian extrovert dan introvert dapat dilihat pada Gambar 1 berikut.

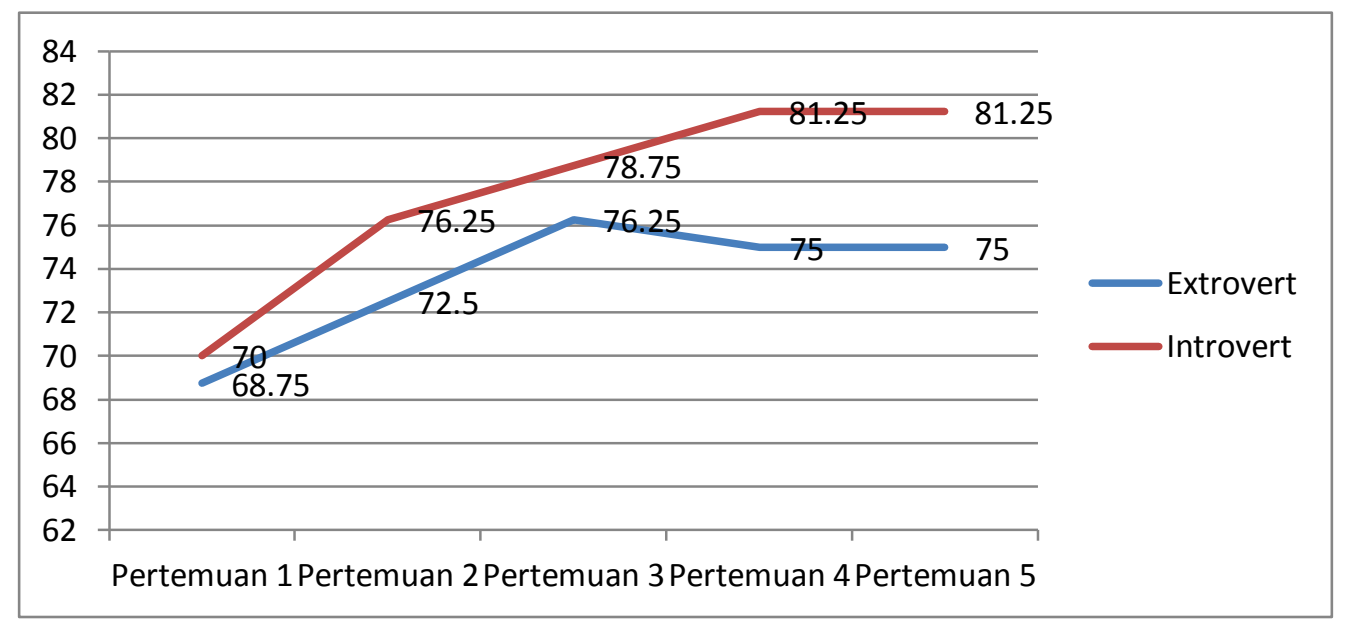

Gambar 1 Persentase Hasil Kemampuan Komunikasi Matematis Tertulis

Pada Gambar 1 dapat di lihat bahwa hasil persentase kemampuan komunikasi matematis introvert lebih tinggi dari pada persentase kemampuan komunikasi matematis extrovert. Hal tersebut sesuai menurut Crow dan Crow (Ulya, 2016) bahwa siswa introvert lebih lancar dalam menulis.

Tingginya kemampuan komunikasi matematis tertulis introvert dari extrovert karena introvert lebih lancar dalam menulis dan merasa nyaman dengan mengkomunikasikan sesuatu melalui tulisan. Introvert yang juga sering di liputi kekhawatiran membuatnya lebih teliti sehingga berhati-hati dalam menjawab soal. Berbeda dengan introvert, extrovert lebih tergesa-gesa dalam mengerjakan soal sehingga membuatnya tidak teliti. Extrovert yang tidak suka membaca menyebabkannya cenderung ingin cepat menyelesaikan soal, sehingga membuatnya jarang mengecek kembali jawaban. Hal tersebut juga dikarenakan extrovert tidak khawatir akan jawaban yang sudah dibuatnya, karenanya kemampuan komunikasi matematis tertulis introvert lebih tinggi dari extrovert.

Untuk hasil kemampuan komunikasi matematis lisan siswa berdasarkan tipe kepribadian extrovert dan introvert dapat dilihat pada Gambar 2. Sedangkan, untuk hasil kemampuan pemahaman matematis siswa berdasarkan tipe kepribadian extrovert dan introvert dapat dilihat pada Gambar 3. 


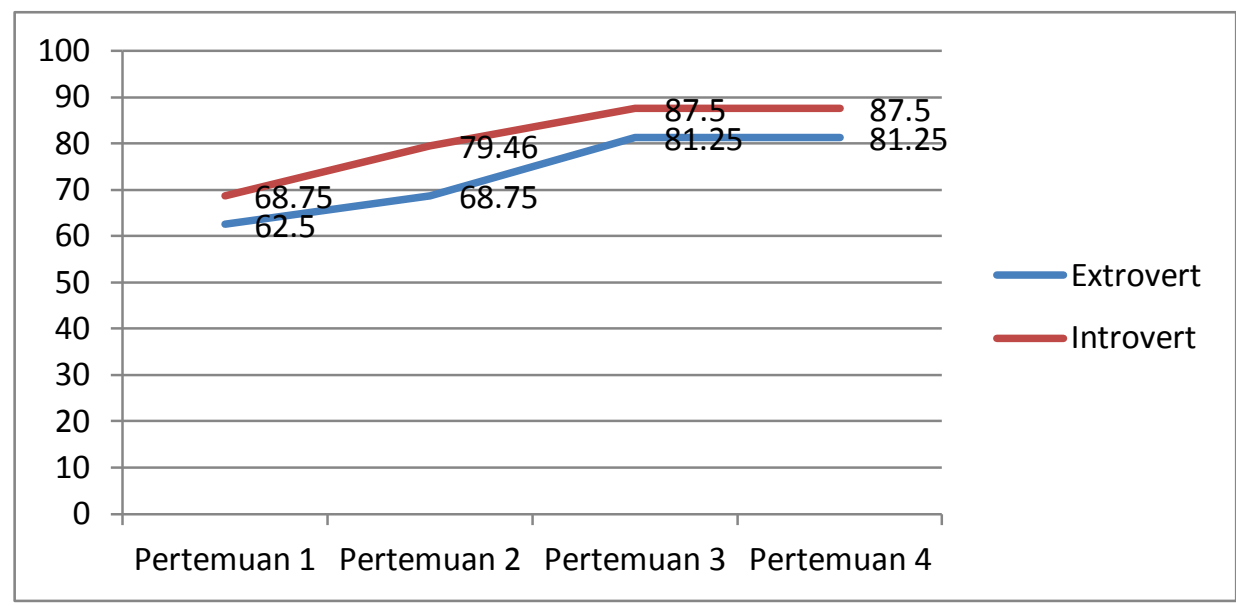

Gambar 2 Persentase Hasil Kemampuan Komunikasi Matematis Lisan

Dari hasil penelitian di dapat bahwa pemahaman matematis siswa introvert lebih tinggi dari extrovert dikarenakan soal tes pemahaman matematis berbentuk tes tertulis. Extrovert lebih fasih berbicara sedangkan introvert merasa nyaman mengekpresikan sifat kepribadiannya dalam tulisan. Baik siswa extrovert maupun introvert ditemukan tidak teliti, tetapi ketidaktelitian extrovert lebih dominan karena sifat kepribadiannya tersebut. Kedua siswa juga di dapat kurang latihan dalam mengerjakan soal-soal bentuk cerita.

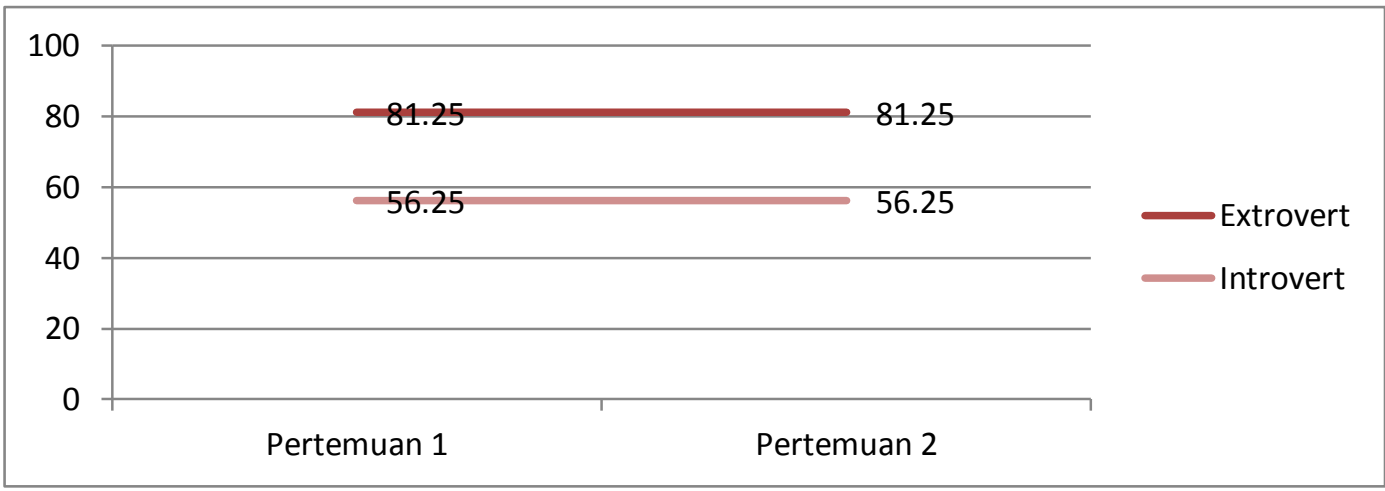

Gambar 3 Persentase Hasil Kemampuan Komunikasi Matematis Tertulis

Dari pertemuan pertama sampai pertemuan keempat terlihat bahwa kesalahan penulisan diketahui tanpa dengan menggunakan simbol matematika yang akurat selalu dilakukan oleh subjek. Sama seperti extrovert, hal ini menandakan subjek kurang latihan mengerjakan soal-soal bentuk cerita.

Kesalahan lainnya yaitu tidak menuliskan perhitungan, tidak menuliskan kesimpulan, dan tidak menggunakan notasi matematika dengan benar. Kesalahankesalahan tersebut karena ketidaktelitian subjek. Ternyata subjek introvert juga ditemukan tidak teliti.

Menurut Feist dan Feist (Gufron dan Risnawita, 2014), bahwa baik extrovert maupun introvert memiliki hubungan yang saling mengisi satu dengan yang lain. Jadi tidak ada satupun individu yang memiliki sisi extrovert secara keseluruhan, sehingga sisi introvert pasti ada walau sedikit begitu pula sebaliknya. 
4. Kesimpulan

Berdasarkan hasil penelitian maka dapat disimpulkan bahwa:

(1) Profil kemampuan komunikasi matematis tertulis siswa extrovert cukup dengan persentase $75 \%$ dan profil kemampuan komunikasi matematis tertulis siswa introvert baik dengan persentase $81,25 \%$

(2) Profil kemampuan komunikasi matematis lisan siswa extrovert baik dengan persentase $81,25 \%$ dan profil kemampuan komunikasi matematis lisan siswa introvert kurang dengan persentase 56,25\%

(3) Profil kemampuan pemahaman matematis siswa extrovert baik dengan persentase $81,25 \%$ dan profil kemampuan pemahaman matematis siswa introvert sangat baik dengan persentase $87,50 \%$.

\section{Pustaka}

Astuti, Anggraini., Leonard. 2015. Peran Kemampuan Komunikasi Matematika Terhadap Prestasi Belajar Matematika Siswa. Jurnal Formatif 2 Hal 102-110 ISSN 2088-351X.

Ghufron, M. N., Risnawita, Rini. 2014. Gaya Belajar Kajian Teoritik. Yogyakarta: Pustaka Pelajar.

Kurniasih, Eka Rachma. 2016. Profil Pemahaman Matematis Mahasiswa Pendidikan Matematika Ditinjau Dari Jenis Kelamin. Jurnal Prima Vol. 5 No. 11 ISSN 23019891 .

Marsigit. 2012. Kajian Penelitian (Review Jurnal Internasional) Pendidikan Matematika. Universitas Negeri Yogyakarta.

Sugiyono. 2013. Metode Penelitian Pendidikan Pendekatan Kuantitatif, Kualitatif, dan $R \& D$. Bandung: Alfabeta.

Sulthani. -. Kemampuan Komunikasi Matematis Siswa Kelas Unggulan dan Siswa Kelas Reguler Kelas X SMA Panjura Malang Pada Materi Logika Matematika. Universitas Negeri Malang.

Tarmidzi, D. S. 2012. Hubungan Antara Tipe Kepribadian: Extrovert dan Introvert Dengan Prestasi Akademik Mahasiswa Fakultas Teknik Universitas Indonesia Program S1 Reguler. Universitas Indonesia.

Ulya, Nur Maziyah. 2016. Pengaruh Metode Pembelajaran dan Tipe Kepribadian Terhadap Hasil Belajar Bahasa Arab (Studi Eksperimen Pada MAN 1 Semarang). Nadwa Vol. 10 No. 1.

Widayanti, Lilis. 2016. Deskripsi Level Kemampuan Siswa SMP Dengan Tipe Kepribadian Cenderung Introvert Dalam Menyelesaikan Masalah Matematika. Jurnal Edukasi Vol 2 No. 1 ISSN 2443-0455. 